\title{
COMPARISON OF STINGING NETTLE ADSORPTION PERFORMANCE TOWARDS ANIONIC AND CATIONIC DYES
}

\author{
BENGÜ ERTAN \\ Espiye Vocational School, Giresun University, Adabük 28500, Düzköy/Giresun, Turkey \\ ๔orresponding author: bengu.ertan@giresun.edu.tr
}

Received August 11, 2021

\begin{abstract}
Stinging nettle was used as lignocellulosic adsorbent for the removal of cationic dye - malachite green (MG), and anionic dye - Congo red (CR), from aqueous solution, without any chemical pretreatment. The adsorption equilibrium data fitted well with the Langmuir model for the adsorption of both dyes, with the calculated maximum adsorption capacity of $270.27 \mathrm{mgg}^{-1}$ and $172.14 \mathrm{mgg}^{-1}$ for MG and CR, respectively. The adsorption process was controlled by the pseudo-second-order model in the adsorption of MG and by the pseudo-first-order model in the adsorption of CR. The thermodynamics modelling displayed that the process was spontaneous and endothermic. The $\pi-\pi$ electron-donor interaction, hydrogen bonds and pore diffusion may also be effective, besides electrostatic interaction between the adsorbate and the adsorbent in the mechanism of MG and CR uptake.
\end{abstract}

Keywords: stinging nettle, malachite green, Congo red, adsorption

\section{INTRODUCTION}

Dyes are used for coloring many products, such as textiles, pharmaceuticals, cosmetics, and food. Each country has obtained dyes from its own unique local sources, and these have developed by spreading around the world through migrations, cultural and commercial exchanges over the centuries. Natural dyes can be obtained from renewable sources, they are compatible with nature and easily degradable, offering UVprotective and antibacterial properties. However, some of their disadvantages, such as the use of large amounts of raw materials and the need for continuity, standardization difficulties, high dyeing costs, and limited color palette, have made the use of synthetic dyes mandatory. ${ }^{1}$ Synthetic dyes consist of two parts, called chromophore and auxochrome. ${ }^{2}$ Chromophore is the part that gives color and it contains azo $(-\mathrm{N}=\mathrm{N}-)$, carbonyl ($\mathrm{C}=\mathrm{O}-)$, methyl $(-\mathrm{CH}=)$, nitro $\left(-\mathrm{NO}_{2}\right)$, and quinoid rings. The auxochrome part, on the other hand, provides the molecule with electrolytic dissolution and the dye molecule to form a salt. Amine $\left(-\mathrm{NH}_{3}\right)$, carboxyl $(-\mathrm{COOH})$, sulfonate ($\left.\mathrm{SO}_{3} \mathrm{H}\right)$, and hydroxyl (-OH) are important auxochromes. ${ }^{3}$ These substances are nonbiodegradable and have a toxic effect on living organisms because of their complex aromatic molecular structure. They reach the human body, as well as aquatic creatures, by entering the food chain. It has been reported that some dyes inhibit the microbial oxidation process in activated sludge and streams. ${ }^{4-6}$ Dyestuffs reflect the sunlight, resulting in aquatic photosynthesis of plants being inhibited, which causes dissolved oxygen to run out.

The dye industry wastewater is chemically complex and diverse because of the difference in the fibers, dyestuffs and chemicals used during operation, as well as final products. Therefore, such wastewater cannot be adequately treated in conventional wastewater treatment plants, ${ }^{7,8}$ as it needs to be characterized first. ${ }^{9}$ Physical, chemical, and biological treatment methods are used for the remediation of wastewater. Among of them, membrane filtration, ion-exchange, coagulation, irradiation and adsorption, as physical treatment techniques, ozonation, photochemical, electrochemical destruction, oxidation as chemical treatment techniques, and decolorization by fungi, other microbial cultures, adsorption by living/dead microbial biomass and anaerobic textile dye bioremediation systems as biological treatment techniques are applied and have various advantages and disadvantages. ${ }^{10}$ 
Adsorption has gained importance among these techniques due to its effectiveness, simplicity, cheapness, and practicality. Although adsorption with activated carbon is very important in cleaning wastewater, the search for alternative adsorbents has continued because of its limitations, such as being expensive and losing effectiveness after regeneration. ${ }^{11,12}$

Agricultural adsorbents have good efficiency in removing pollutants, such as heavy metals, ${ }^{13}$ COD ${ }^{14}$ phenols, ${ }^{15}$ gasses ${ }^{16}$ and dyes. ${ }^{17,18}$ Many researchers have studied and obtained good results using agricultural wastes, such as grape waste, ${ }^{19}$ bagasse, ${ }^{20}$ bamboo, ${ }^{21,22}$ coconut shell, ${ }^{23}$ rice husk, ${ }^{24}$ etc. for the removal of $\mathrm{MG}$, and sunflower stalks, ${ }^{25}$ coir pith, ${ }^{26}$ leaf powder, ${ }^{27}$ tamarind fruit shell, ${ }^{28}$ palm kernel seed coat, ${ }^{29}$ cashew nutshell, ${ }^{30}$ pine cone powder, ${ }^{31}$ jute fiber, ${ }^{32}$ etc. for the removal of CR. They are widespread, renewable, cheap, environmentally friendly, and usually used without or with a minimum physical or chemical pretreatment (only washing, drying, grinding), thus reducing energy costs. $^{33}$ Agricultural adsorbents are lignocellulosic, the main components of which are lignin, cellulose and hemicelluloses. ${ }^{34,35}$ Cellulose and hemicelluloses are polysaccharides found in the cell wall of plants. Lignin, on the other hand, is the main component of phenyl propane and forms lignification by filling the cellulose micelles. ${ }^{36}$ Compounds with this large molecular weight contain smaller-sized extractive components. These are various polyphenolic groups that bind dyes by mechanisms, such as complexation, ion exchange, and hydrogen bonding. ${ }^{37}$

Stinging nettle or Urtica dioica is a perennial plant that has been used with all of the plant parts (stem, leaves, roots, and seeds) for centuries in many areas, such as medicine, cosmetics, food, textiles, fiber, etc. The content of nettle fibre varies slightly depending on the extraction method, and it contains approximately $80 \%$ cellulose, $10 \%$ hemicelluloses, and 3\% lignin. ${ }^{38}$ Its leaves contain triterpenoids, alkaloids, polyphenols, and tannins and are also rich in acetylcholine, histamine, serotonin, formic acid, vitamins $\mathrm{A}$ and $\mathrm{C}$; the plant has good anti-static, thermoregulation, and transpiration properties. ${ }^{39-41}$ Nettle fiber has low specific weight, is soft and resistant, and has been demonstrated to have an ideal adsorption potential. ${ }^{41}$ There are several studies in the literature on the adsorption potential of stinging nettle. It has been found that Urtica dioica $\mathrm{L}$. is very effective in the competitive adsorption of heavy metals $\mathrm{Pb}, \mathrm{Cu}$ and $\mathrm{Cd}^{42}$ Another study reported that Urtica dioica proved to be an alternative adsorbent with up to $91.67 \%$ dye removal under optimized conditions. ${ }^{43}$ Urtica dioica leaves alone and in a calcium alginate composite have been used to remove crystal violet cationic dye and demonstrated a maximum adsorption capacity of 1790 and $1107 \mathrm{mg} / \mathrm{g}$, respectively. ${ }^{44}$

In this study, the adsorption performance of stinging nettle has been compared for MG, as a cationic dye, and CR, an anionic dye, and the corresponding adsorption mechanisms have been explained.

\section{EXPERIMENTAL \\ Preparation}

Stinging nettle was picked locally, washed several times with deionized water and dried firstly at ambient temperature and then at $80^{\circ} \mathrm{C}$ for $48 \mathrm{~h}$ in the oven to remove the moisture. The samples were ground and passed through a $0.5 \mathrm{~mm}$ sieve. The adsorbent was stored in a dark bottle until the adsorption experiments. The stock solutions of MG and CR were prepared 1 $\mathrm{gL}^{-1}$ with double distilled water using malachite green oxalate (chemical formula: $\mathrm{C}_{50} \mathrm{H}_{52} \mathrm{~N}_{4} \mathrm{O}_{8} \cdot \mathrm{C}_{2} \mathrm{H}_{2} \mathrm{O}_{4}$, IUPAC name: [4-[[4-(dimethylamino) phenyl]phenylmethylidene] cyclohexa-2,5-dien-1-ylidene]dimethylazanium; 2-hydroxy-2-oxoacetate; oxalic acid, molecular weight: $927 \mathrm{gmol}^{-1}$ ) and Congo red (chemical formula: $\mathrm{C}_{32} \mathrm{H}_{22} \mathrm{~N}_{6} \mathrm{Na}_{2} \mathrm{O}_{6} \mathrm{~S}_{2}$, IUPAC name: disodium; 4-amino-3-[[4-[4-[(1-amino-4sulfonatonaphthalen-2-yl) diazenyl]phenyl]phenyl]diazenyl]naphthalene-1sulfonate, molecular weight: $696.7 \mathrm{gmol}^{-1}$ ). The stock solutions of dyes were diluted to prepare the desired concentrations. The $\mathrm{pH}$ of the solutions was adjusted with $\mathrm{HCl}(0.1 \mathrm{M})$ and $\mathrm{NaOH}(0.1 \mathrm{M})$. The chemicals were of analytical grade and supplied by Sigma Aldrich.

\section{Characterization}

Infrared (IR) spectra of the initial adsorbent and the dye-loaded adsorbent were recorded by using a Bruker Optics Vertex 70 Fourier Transform Infrared Spectrometer (FT-IR), equipped with an ATR (Attenuated Total Reflection) device, and the data were reported in reciprocal centimeters $\left(\mathrm{cm}^{-1}\right)$ in the range of $4000-400 \mathrm{~cm}^{-1}$ (Bruker Optik $\mathrm{GmbH}$, Ettlingen, Germany). The $\mathrm{pH}$ and the isoelectronic point were measured by a $\mathrm{pH}$ meter (Ohaus Starter $3100)$.

\section{Adsorption studies}

The adsorption experiments were carried out in the batch model. In the batch model, $50 \mathrm{~mL}$ of dye 
solution at different $\mathrm{pH}$ values and the respective amount of adsorbent were stirred for $2 \mathrm{~h}$ at room temperature $\left(25^{\circ} \mathrm{C}\right)$ and at $200 \mathrm{rpm}$, in an incubator shaker, and then centrifuged at $3000 \mathrm{rpm}$ for the separation of the liquid phase. The concentration of the dye solution was determined using a UV-visible spectrophotometer (Mapada-UV6100PCS Double Beam Spectrophotometer) - $\lambda_{\max }$ (water): $618 \mathrm{~nm}$ (MG) and $\lambda_{\max }$ (water): $488 \mathrm{~nm}$ (CR).

The amount of adsorbed dye at the equilibrium time was calculated using Equation (1):

$$
Q_{e}=\frac{c_{0}-c_{g}}{W} \times V
$$

where $c_{0}$ is the initial dye concentration $\left(\mathrm{mgL}^{-1}\right), \mathrm{c}_{\mathrm{e}}$ is the final dye concentration, $\mathrm{Q}_{\mathrm{e}}$ is the adsorbed dye per gram of adsorbent at equilibrium time $\left(\mathrm{mgg}^{-1}\right), \mathrm{V}$ is the volume of dye solution (L) and $\mathrm{W}$ is the mass of adsorbent (g). All experiments were performed in triplicate and the mean values were used in data analysis.

\section{Adsorption isotherms}

Adsorption isotherms are obtained by plotting the amount of soluble adsorbent $\mathrm{Q}_{\mathrm{e}}\left(\mathrm{mgg}^{-1}\right)$ per unit weight of the adsorbent, against the solute concentration $\mathrm{c}_{\mathrm{e}}\left(\mathrm{mgL}^{-1}\right)$ remaining in the solution at a constant temperature.

Isotherm models for the single-component systems that express the adsorption isotherms mathematically are Langmuir, Freundlich, Redlich-Peterson, BET, Tempkin, and Koble-Corrigan. There are also multicomponent isotherm models derived from these singlecomponent system isotherms. Multi-component isotherm models are also used for the adsorption of wastewater containing more than one pollutant. The data obtained from these isotherm models give important information about the adsorption mechanisms and the surface activities of the adsorbent. ${ }^{45-48}$

The Langmuir isotherm model assumes that the surface of the adsorbent is homogenous and covered by a monolayer of the adsorbate. The linear Langmuir equation is expressed as:

$\frac{1}{Q_{t}}=\frac{1}{Q_{\max }}+\left(\frac{1}{Q_{\max }}\right) \frac{1}{c_{e}}$

where $c_{e}\left(\mathrm{mgL}^{-1}\right)$ is equilibrium dye concentration, $Q_{e}$ $\left(\mathrm{mgg}^{-1}\right)$ is adsorption capacity at equilibrium, $\mathrm{Q}_{\max }$ $\left(\mathrm{mgg}^{-1}\right)$ is maximum adsorption capacity and $K_{\mathrm{L}}\left(\mathrm{Lmg}^{-}\right.$ ${ }^{1}$ ) is the Langmuir constant. The $1 / \mathrm{Q}_{\mathrm{e}}$ versus $1 / \mathrm{c}_{\mathrm{e}}$ gives a straight line with an intercept of $1 / \mathrm{Q}_{\max } \mathrm{K}_{\mathrm{L}}$ and a slope of $1 / \mathrm{Q}_{\max }{ }^{47}$

The Freundlich isotherm equation is expressed as follows:

$$
\ln Q_{p}=\ln K_{F}+\frac{1}{n} \ln c_{e}
$$

where $\mathrm{K}_{\mathrm{F}}$ is the Freundlich constant, $\mathrm{n}\left(\mathrm{mgL}^{-1}\right)$ is the heterogeneity factor, which is related to the intensity of adsorption. The values of $\mathrm{K}_{\mathrm{F}}$ and $\mathrm{n}$ were calculated from the intercept and the slope of the linear plot of $\ln$ $\mathrm{Q}_{\mathrm{e}} \mathrm{vs} \ln \mathrm{C}_{\mathrm{e}}{ }^{46}$

\section{Adsorption kinetics}

The adsorption kinetic models, pseudo-first-order model, second-order model and intraparticle diffusion models have been examined for the experimental data to explain the adsorption kinetics.

The Lagergren pseudo-first-order rate expression can be given as:

$\log \left(Q_{e}-Q_{t}\right)=\log Q_{e}-\frac{k_{1}}{2.303} t$

where $Q_{e}$ and $Q_{t}\left(\mathrm{mgg}^{-1}\right)$ are the amount of dye adsorbed at equilibrium and at the respective time, respectively, and $\mathrm{k}_{1}\left(\mathrm{~min}^{-1}\right)$ is the rate constant of adsorption. It is calculated as $\mathrm{k}_{1}$ (slope) and intercepts $\left(\log \mathrm{Q}_{\mathrm{e}}\right)$ from the linear plots of $\log \left(\mathrm{Q}_{\mathrm{e}}-\mathrm{Q}_{\mathrm{t}}\right)$ versus time (min).

The pseudo-second-order kinetic model is shown in Equation (5), where $\mathrm{k}_{2}$ is the rate constant of adsorption $\left(\mathrm{gmg}^{-1} \min ^{-1}\right), \mathrm{Q}_{\mathrm{e}}$, and $\mathrm{Q}_{\mathrm{t}}$ are the amount of dye adsorbed $\left(\mathrm{mgg}^{-1}\right)$ at equilibrium and time (min), respectively. The values of $\mathrm{k}_{2}$ and $\mathrm{Q}_{\mathrm{e}}$ were calculated from the intercepts $\left(1 / \mathrm{k}_{2} \mathrm{Q}_{\mathrm{e}}^{2}\right)$ and slopes $\left(1 / \mathrm{Q}_{\mathrm{e}}\right)$ of the plots of $\mathrm{t} / \mathrm{Q}_{\mathrm{t}} \mathrm{vs}$. time $(\mathrm{min})$, respectively. ${ }^{49,50}$

$\frac{1}{Q_{n}}=\frac{1}{k_{2} Q_{0}^{2}}+\frac{t}{Q_{k}}$

The intraparticle diffusion model was explored by Weber and Morris, and expressed by the following equation:

$Q_{t}=\mathrm{K}_{\mathrm{i}} \mathrm{t}^{1 / 2}+\mathrm{c}$

where $Q_{t}$ is the adsorption capacity at any time $t, K$ $\left(\mathrm{mg} \mathrm{g} \mathrm{g}^{-1} \mathrm{~min}^{-1 / 2}\right.$ ) is the intraparticle diffusion rate constant and $\mathrm{c}\left(\mathrm{mg} \mathrm{g}^{-1}\right)$ is the intraparticle diffusion constant relating to the thickness of the boundary layer. The values of $K_{i}$ and $c$ were calculated from the slopes and intercepts of the plots of $\mathrm{Q}_{\mathrm{t}} \mathrm{vs} . \mathrm{t}^{1 / 2}$, respectively. ${ }^{51}$

\section{Adsorption thermodynamics}

Thermodynamic parameters, i.e. Gibbs' free energy change $\Delta G^{\circ}\left(\mathrm{kJ} \cdot \mathrm{mol}^{-1}\right)$, enthalpy change $\Delta H^{\circ}$ $\left(\mathrm{kJ} \cdot \mathrm{mol}^{-1}\right)$ and entropy change $\Delta S^{\circ}\left(\mathrm{J} \cdot \mathrm{mol}^{-1} \mathrm{~K}^{-1}\right)$, were calculated using Equations (7) and (8):

$\ln \left(\frac{\mathrm{Qe}}{\mathrm{ce}}\right)=\frac{\Delta F^{\circ}}{\mathrm{R}}-\frac{\Delta \mathrm{H}^{\mathrm{S}}}{\mathrm{RT}}$

$\Delta \mathrm{G}^{\circ}=\Delta \mathrm{H}^{\circ}-\mathrm{T} \Delta \mathrm{S}^{\circ}$

where $Q_{e}$ is the quantity of dyes $\left(\mathrm{mgg}^{-1}\right)$ adsorbed, $C_{e}$ $\left(\mathrm{mgL}^{-1}\right)$ is the dye concentration at equilibrium, $\mathrm{R}$ is the universal gas constant $\left(8.314 \mathrm{~J} \cdot \mathrm{mol}^{-1} \mathrm{~K}^{-1}\right), \mathrm{T}(\mathrm{K})$ is the adsorption temperature. The values of $\Delta \mathrm{H}^{\circ}$ and $\Delta \mathrm{S}^{\circ}$ were obtained from the slopes and intercepts of the Van't Hoff plots of $\ln \left(\mathrm{Q}_{\mathrm{e}} / \mathrm{c}_{\mathrm{e}}\right)$ vs. 1/T(K), respectively, thereafter $\Delta \mathrm{G}^{\circ}$ values were determined from Equation (8). ${ }^{52,53}$

\section{RESULTS AND DISCUSSION \\ Characterization of stinging nettle}

The characterization of an adsorbent is mandatory for its possible application and determines whether the adsorbent can be used in basic treatment plants, by assessing its adsorption 
capacity and its efficiency. FTIR analysis was applied to determine the functional groups that bind the dye molecules onto the stinging nettle adsorbent. In Figure 1 (a), the highest peak at $3414 \mathrm{~cm}^{-1}$ indicates hydrogen bonds caused by the presence of hydroxyl $(-\mathrm{OH})$, amine $(-\mathrm{NH})$ and ($\mathrm{COOH})$ groups, and $(-\mathrm{COOH})$ groups, and the peak at $2923 \mathrm{~cm}^{-1}$ is assigned to $\mathrm{C}-\mathrm{H}$ stretching of alkane. The peak of $\mathrm{C}=\mathrm{O}$ stretching in the carboxyl group is seen at $1655 \mathrm{~cm}^{-1}$ and the peak at $1320 \mathrm{~cm}^{-1}$ proves the presence of alcohol, ether, carboxylic acid, or ester. The band at $1032 \mathrm{~cm}^{-1}$ indicates the $\mathrm{C}-\mathrm{H}$ stretching of carboxylic acid and alcohols and the peaks in the regions of 1420 , $873 \mathrm{~cm}^{-1}$, and $614 \mathrm{~cm}^{-1}$ belong to organic, aromatic compounds. However, the peaks of $\mathrm{OH}$ at $3414 \mathrm{~cm}^{-1}, \mathrm{CH}$ at $2923 \mathrm{~cm}^{-1}$, asymmetric $\mathrm{COO}$ at $1655 \mathrm{~cm}^{-1}$ are characteristic peaks of cellulose in the adsorbent structure. The peak at $1420 \mathrm{~cm}^{-1}$ shows the aromatic skeletal vibrations and the peak around $1650 \mathrm{~cm}^{-1}$ stands for the carbonyl $\mathrm{C}=\mathrm{O}$ stress conjugated with aromatic rings in lignin. $^{54-55}$
The FTIR spectra of MG-loaded and CRloaded adsorbent are seen in Figure 1 (b) and (c), respectively. The broad $\mathrm{OH}$ band at $3414 \mathrm{~cm}^{-1}$ shrank after adsorption. The position of some peaks shifted to slightly higher values, namely, from 2923 to 2958 and $2961 \mathrm{~cm}^{-1}$, from 1655 to $1650 \mathrm{~cm}^{-1}$, from 1320 to $1340 \mathrm{~cm}^{-1}$, from 1032 to 1058 and $1062 \mathrm{~cm}^{-1}$. The intensity of the peaks decreased, while some of them, such as those at 1240 and $873 \mathrm{~cm}^{-1}$ disappeared from the spectrum after the adsorption. All of these modifications indicate the interaction of the dyes with the adsorbent, and the involvement of the $\mathrm{C}-\mathrm{O}$ and $\mathrm{O}$ $\mathrm{H}$ groups in binding the dyes. The zeta potential, which is an important parameter, determines the surface charge of the adsorbent and explains the interactions between the dyes and the adsorbent in the adsorption process. Similar findings have been reported previously. ${ }^{56-57}$ The point of zero charges (pzc) of stinging nettle was found as 8. It means the overall surface of the adsorbent was positively charged at $\mathrm{pH}<8$ and negatively charged in the basic medium.

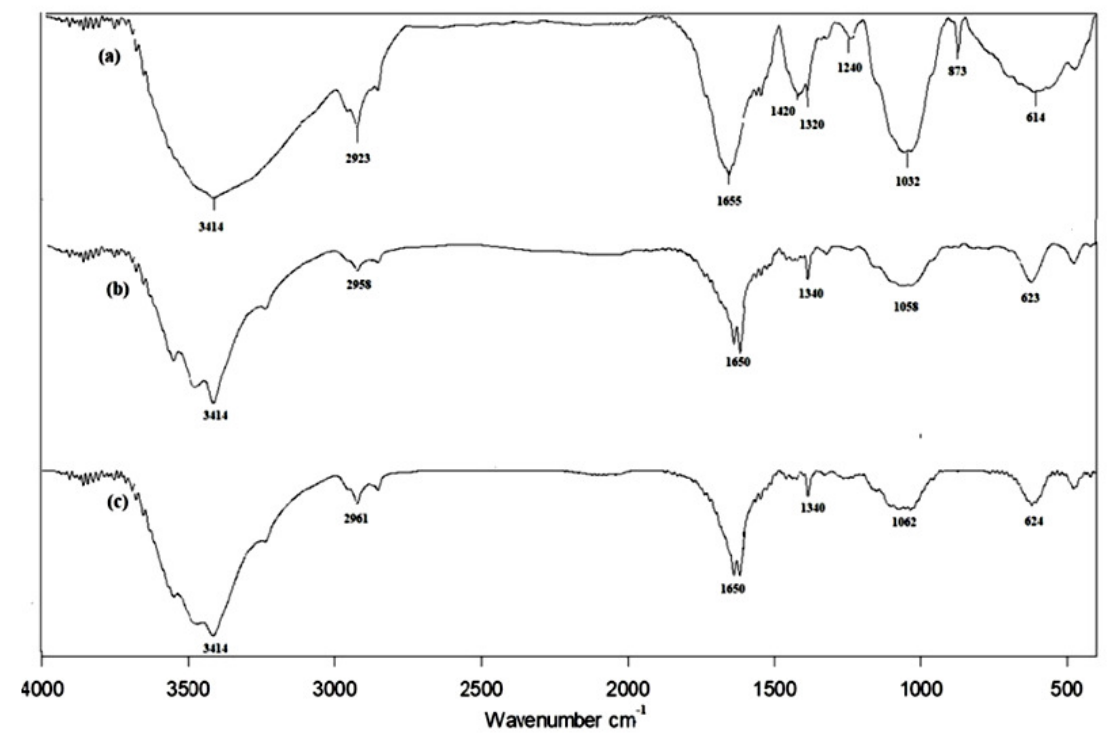

Figure 1: FTIR spectra of initial stinging nettle (a), as well as MG loaded (b) and CR loaded (c) stinging nettle

\section{Effect of $\mathbf{p H}$}

In Figure 2, the adsorption capacity was examined in the $\mathrm{pH}$ range of 2 to 10 . The adsorption capacity of stinging nettle towards MG was $20 \mathrm{mgg}^{-1}$ at $\mathrm{pH} \mathrm{2,} \mathrm{which} \mathrm{was} \mathrm{the} \mathrm{minimum}$ value. It increased sharply at $\mathrm{pH} 4$ and reached its maximum value of 56.69 at $\mathrm{pH}$ 6. With further increasing $\mathrm{pH}$ values, the adsorption capacity remained nearly unchanged. It would be appropriate to explain this situation together with the zeta potential, which reveals the charge distribution on the adsorbent surface. In a low $\mathrm{pH}$ solution, the adsorbent surface is positively charged due to the increased presence of $\mathrm{H}^{+}$ions in the solution and repulsion occurs between the positively charged cationic dye, MG, and positively charged adsorbent surface, and the adsorption capacity decreases. In the increasing $\mathrm{pH}$ media, the surface of the adsorbent is negatively charged, and strong electrostatic attraction occurs between cationic dye, MG, and the surface of the stinging nettle. With a similar 
explanation, we would expect the adsorption capacity of $\mathrm{CR}$, an anionic dye, to be higher at lower $\mathrm{pH}$ values as the surface charge of stinging nettle is positive at $\mathrm{pH}<8 .{ }^{58,59}$ As can be seen in Figure 2, the adsorption of $\mathrm{CR}$ is high at low $\mathrm{pH}$ and showed little change with the increasing $\mathrm{pH}$ of the solution. However, the adsorption capacity towards $\mathrm{CR}$ was lower than towards MG for all the $\mathrm{pH}$ values used in the study, except $\mathrm{pH} 2$. The maximum adsorption capacity of 36.83 was obtained at $\mathrm{pH} 7$. High adsorption capacities towards both dyes were obtained at values in the $\mathrm{pH}$ range of 4-9, and these values are the natural $\mathrm{pH}$ range of all kinds of water resources. ${ }^{60}$

The mechanism for the adsorption of the anionic dye CR and cationic dye MG from aqueous solution onto stinging nettle is shown in Scheme 1. In acidic media, the oxygen atoms on the adsorbent surface interact with water and the surface of the adsorbent becomes positively charged, which favors the anionic dye, $\mathrm{CR}$, as seen in Equations (a) and (b) in Scheme 1. In basic media, the carboxylic acid of the adsorbent loses a proton and becomes negatively charged. Electrostatic attraction occurs between the opposite charges of the adsorbent and MG, as seen in Equations (c) and (d). ${ }^{61,62}$ It is noted that the most effective forces in the adsorption mechanism of nettle are electrostatic interactions, and $\mathrm{CR}$ adsorption at $\mathrm{pH}<7$ and $\mathrm{MG}$ adsorption at $\mathrm{pH}>7$ give good results. Other forces, hydrogen bonding between the hydrophilic functional groups on the stinging nettle (proven by FTIR spectra) and the alkyl hydrogens on MG and CR molecules, $\pi-\pi$ interactions between the aromatic rings of the stinging nettle and $\mathrm{MG}$ and $\mathrm{CR}$ molecules are also involved in the adsorption mechanism. ${ }^{63,64}$

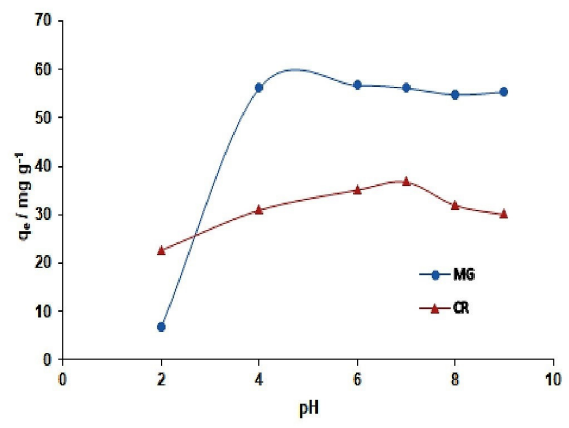

Figure 2: Effect of $\mathrm{pH}$ on adsorption of $\mathrm{MG}$ and $\mathrm{CR}$ onto stinging nettle

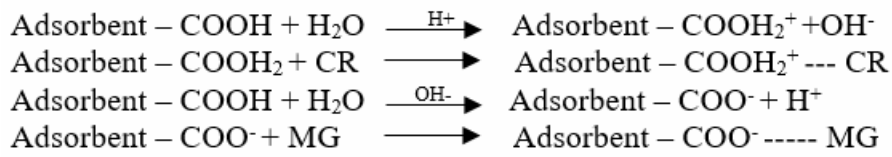

Scheme 1: Adsorption mechanism of anionic dye CR and cationic dye MG onto the stinging nettle adsorbent

\section{Effect of initial dye concentration and contact time}

The effect of initial dye concentration and contact time on the adsorption capacity was studied in the range of 50-300 mgL $\mathrm{mL}^{-1}$ and from 15 to 200 minutes. As can be seen in both graphs in Figure 3, the amount of dye molecules adsorbed per unit mass of stinging nettle increased with increasing time because of the settling of dye molecules in the adsorption sites, which are highly available. While the increase in the adsorption capacity was rapid in the first minutes, it slowed down over time because of the saturation of the binding sites. After the rapid and then slow increase in the adsorption capacity, the adsorption equilibrium was reached in 75 minutes for MG and 120 minutes for CR. As can be seen in Figure 3, as the dye concentration increased, the adsorption reached equilibrium later. This effect is especially noticeable at $200 \mathrm{mgL}^{-1}$ and higher concentrations. The reason for this is that a fixed adsorption amount of dye molecules at low concentration settles on the number of adsorption sites on the stinging nettle surface. From this, it can be concluded that the usable sites on the adsorbent surface have a limiting effect on dye adsorption. ${ }^{65}$ The presence of negative sites on the lignocellulosic adsorbent surface and the presence of binding groups, such as carboxyl and hydroxyl 


\section{BENGÜ ERTAN}

groups, of the adsorbent cause a high-affinity adsorbent-adsorbate relationship with positively charged $\mathrm{MG}$, resulting in higher adsorption capacity and shorter equilibrium time, compared to $\mathrm{CR}$, as remarked in Figure 3 for $\mathrm{MG}$.
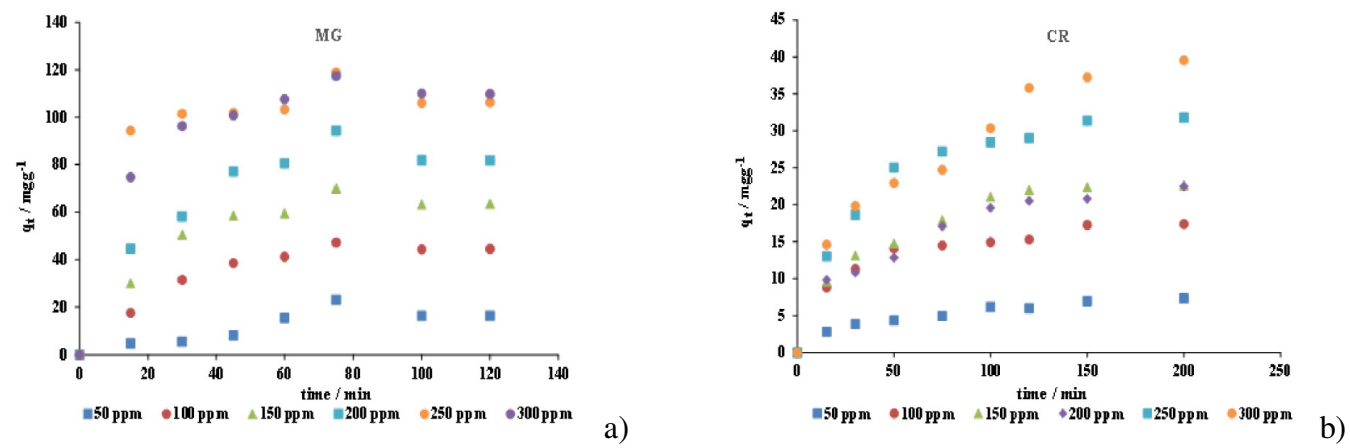

Figure 3: Effects of initial dye concentration and contact time on the adsorption of MG (a) and CR (b) onto stinging nettle

\section{Adsorption isotherms}

Adsorption isotherm studies were carried out to explain the surface properties and the relationship between the adsorbate and the adsorbent, as well as to determine the adsorption capacity, which is decisive in measuring the performance of the adsorbent. The Langmuir and Freundlich isotherm models, which are most commonly used, were applied to describe the adsorption process. ${ }^{46,47}$ Adsorption isotherms were measured by varying the $\mathrm{MG}$ and $\mathrm{CR}$ initial concentration at a constant temperature. The experimental curves were presented in Figure 4. The adsorption parameters, shown in Table 1, were calculated from Langmuir and Freundlich isotherm equations and the data revealed the adsorption mechanism, surface properties, and the affinity of the adsorbent. $\mathrm{Q}_{\max }\left(\mathrm{mgg}^{-1}\right)$ maximum adsorption capacity is estimated by the Langmuir model when all available binding sites are occupied by dye molecules, and it supports the evaluation of the adsorption performance. $\mathrm{K}_{\mathrm{L}}$
$\left(\mathrm{Lmg}^{-1}\right)$ is the Langmuir constant related to the free energy adsorption, the other parameter in the Langmuir model is a dimensionless constant ' $\mathrm{R}_{\mathrm{L}}$ ', referred to as the separation factor. ${ }^{66} \mathrm{R}_{\mathrm{L}}$ values indicate whether the biosorption reaction is favorable or unfavorable, as shown below:

$\mathrm{R}_{\mathrm{L}}>1$, unfavorable;

$\mathrm{R}_{\mathrm{L}}<0$, unfavorable;

$\mathrm{R}_{\mathrm{L}}=1$, favorable (linear);

$0<\mathrm{R}_{\mathrm{L}}<1$, favorable;

$\mathrm{R}_{\mathrm{L}}=0$, irreversible.

The Langmuir isotherm model had higher correlation coefficient $\left(\mathrm{R}^{2}\right)$ values of 0.9914 for MG and 0.9883 for $\mathrm{CR}$, and presented a better fit than the Freundlich isotherm model. The Langmuir isotherm presents a model in which the adsorption is considered a monolayer process, the distribution of the adsorption sites is homogeneous, and the adsorption energy is constant. Adsorbate molecules can act on the surfaces of adsorbents and interactions between adsorbate molecules can be ignored.

Table 1

Parameters of different isotherm models for adsorption of MG and CR onto stinging nettle

\begin{tabular}{lccc}
\hline Models & Parameter & MG & CR \\
\hline \multirow{4}{*}{ Langmuir } & $\mathrm{Q}_{\max }\left(\mathrm{mgg}^{-1}\right)$ & 270.27 & 172.414 \\
& $\mathrm{~K}_{\mathrm{L}}\left(\mathrm{Lmg}^{-1}\right)$ & 0.0234 & 0.0009 \\
& $\mathrm{R}_{\mathrm{L}}$ & 0.1459 & 0.8163 \\
& $\mathrm{R}^{2}$ & 0.9914 & 0.9883 \\
\hline \multirow{3}{*}{ Freundlich } & $\mathrm{n}$ & 1.1888 & 0.9923 \\
& $\mathrm{~K}_{\mathrm{F}}\left(\mathrm{Lmg}^{-1}\right)$ & 5.4043 & 0.1768 \\
& $\mathrm{R}^{2}$ & 0.9820 & 0.9749 \\
\hline
\end{tabular}



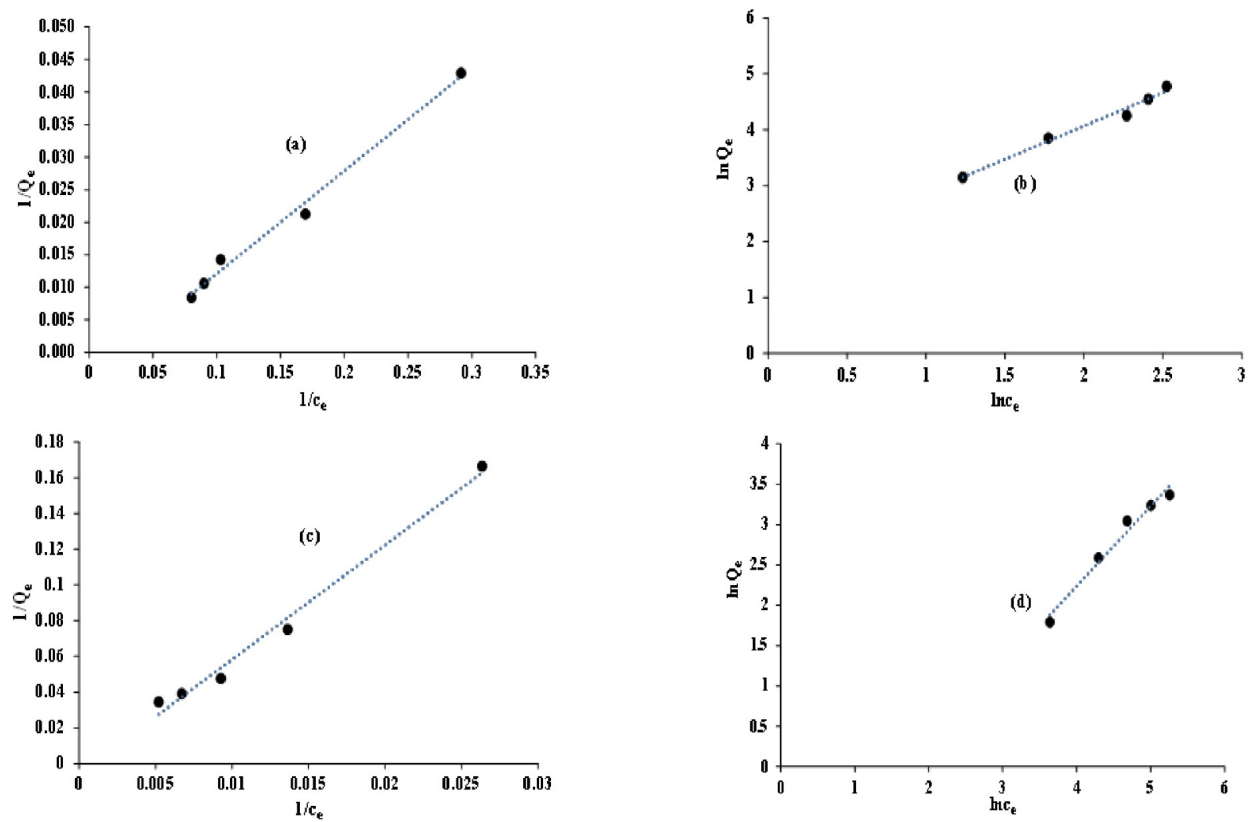

Figure 4: Langmuir and Freundlich isotherm models for adsorption of MG (a), (b) and CR (c), (d) onto stinging nettle

Table 2

Maximum adsorption capacities of various agricultural adsorbents in reported studies for the removal of MG and CR

\begin{tabular}{lcc}
\hline \multirow{2}{*}{ Adsorbent } & \multicolumn{2}{c}{ Maximum adsorption capacity $\left(\mathrm{Q}_{\max }\right)\left(\mathrm{mgg}^{-1}\right)$} \\
\cline { 2 - 3 } & \multicolumn{1}{c}{$\mathrm{MG}$} & $\mathrm{CR}$ \\
\hline Grape waste & $263.7^{19}$ & \\
Bamboo activated $\mathrm{K}_{2} \mathrm{CO}_{3}$ & $42.18^{22}$ & $11.89^{21}$ \\
Bagasse fly ash & $214.63^{23}$ & \\
Coconut shell & $151.51^{24}$ & \\
Basic-modified rice husk & & $37.8^{25}$ \\
Sunflower stalks & & $6.7^{26}$ \\
Coir pith & & $72^{27}$ \\
Azadirachta indica leaf powder & & $10.48^{28}$ \\
Tamarind fruit shell & & $66.23^{29}$ \\
Palm kernel seed coat & & $5.18^{30}$ \\
Cashew nut shell & & $32.65-40.19^{31}$ \\
Raw pine-acid treated pine cone powder & & $136.6^{32}$ \\
Jute fiber & & 172.41 \\
This study & & \\
\hline
\end{tabular}

With agitation, the solution is homogenized, and although the adsorbent is not microscopically uniform, the adsorption can be represented by the Langmuir model. ${ }^{67-69}$ As can be seen in Table 2, the $R_{L}$ value was between 0 and 1 for both $C R$ and $\mathrm{MG}$ adsorption, indicating that the adsorption was "favorable". $\mathrm{K}_{\mathrm{F}}$ and $\mathrm{n}$ are Freundlich constants related to the bonding energy and intensity of adsorption, respectively. MG exhibited better favorability of adsorption and higher affinity to the adsorbent, with greater $\mathrm{K}_{\mathrm{F}}$ and $n$ values. The maximum adsorption capacities of stinging nettle towards $\mathrm{MG}$ and $\mathrm{CR}$ were 270.27 and $172.414 \mathrm{mgg}^{-1}$, respectively. Thus, stinging nettle showed excellent performance, in comparison with other adsorbents. ${ }^{19-32}$

\section{Adsorption kinetics}

The kinetic study is important to understand the dynamics and mechanism of adsorption. 


\section{BENGÜ ERTAN}

Migration of adsorbate molecules on the adsorbent surface occurs in several stages (external surface, molecular, and pore diffusion). The adsorption of the dye molecule can occur by one of these steps or a combination of them. ${ }^{70-72}$ To explain the residence time, the experiments were conducted at different time intervals, and the pseudo-first-order and the pseudo-second-order kinetic models were applied to eliminate timedependent data. ${ }^{49}$ The equations and curves were presented in Figure 5.

The parameters, $\mathrm{k}_{1}\left(\mathrm{~min}^{-1}\right)$ and $\mathrm{k}_{2}\left(\mathrm{gmg}^{-1} \min ^{-1}\right)$ are adsorption constants of the pseudo-first-order model and the pseudo-second-order model, respectively, $\mathrm{Q}_{\mathrm{e}}$ is adsorption capacity at equilibrium $\left(\mathrm{mgg}^{-1}\right)$, the linear regression correlation coefficient $\left(\mathrm{R}^{2}\right)$ values are generally
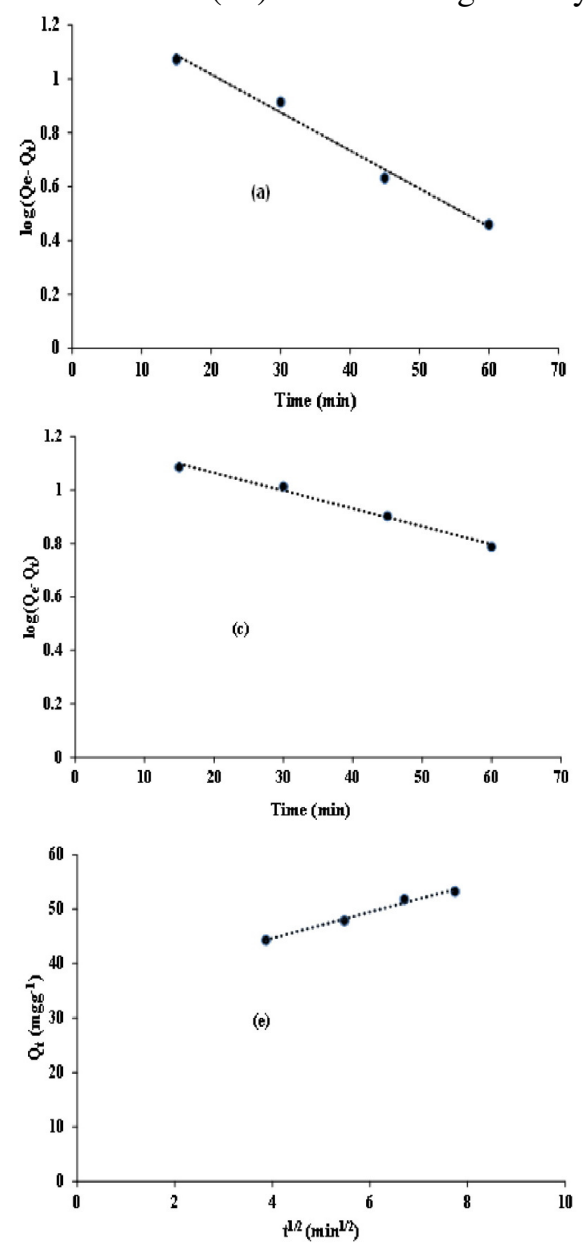

Figure 5: Pseudo-first-order, pseudo-second-order kinetic models and intraparticle diffusion model for adsorption of MG (a), (b), (e) and CR (c), (d), (f), respectively, onto stinging nettle

used to select the best fitting model, as shown in Table 3. According to Table 3, the pseudosecond-order kinetic model gave better results with the $\mathrm{R}^{2}$ value of 0.9988 ; and the $\mathrm{Q}_{\mathrm{e}}$ value, calculated from the model $\left(57.471 \mathrm{mgg}^{-1}\right)$ was also very close to the experimental $\mathrm{Q}_{\mathrm{e}}$ value (56.16 $\mathrm{mgg}^{-1}$ ) for the adsorption of $\mathrm{MG}$ onto stinging needle. The pseudo-second model assumes chemical interactions between dye molecules and polar functional groups in the adsorbent. $^{73}$ In the adsorption of $\mathrm{CR}$ onto the stinging nettle, the pseudo-first-order model is more compatible with the adsorption data than the pseudo-second-order model, considering both the $\mathrm{R}^{2}$ value (0.9894) and the closeness of the calculated $\mathrm{Q}_{\mathrm{e}}$ value (15.791) to the experimental $\mathrm{Q}_{\mathrm{e}}$ value (17.285).
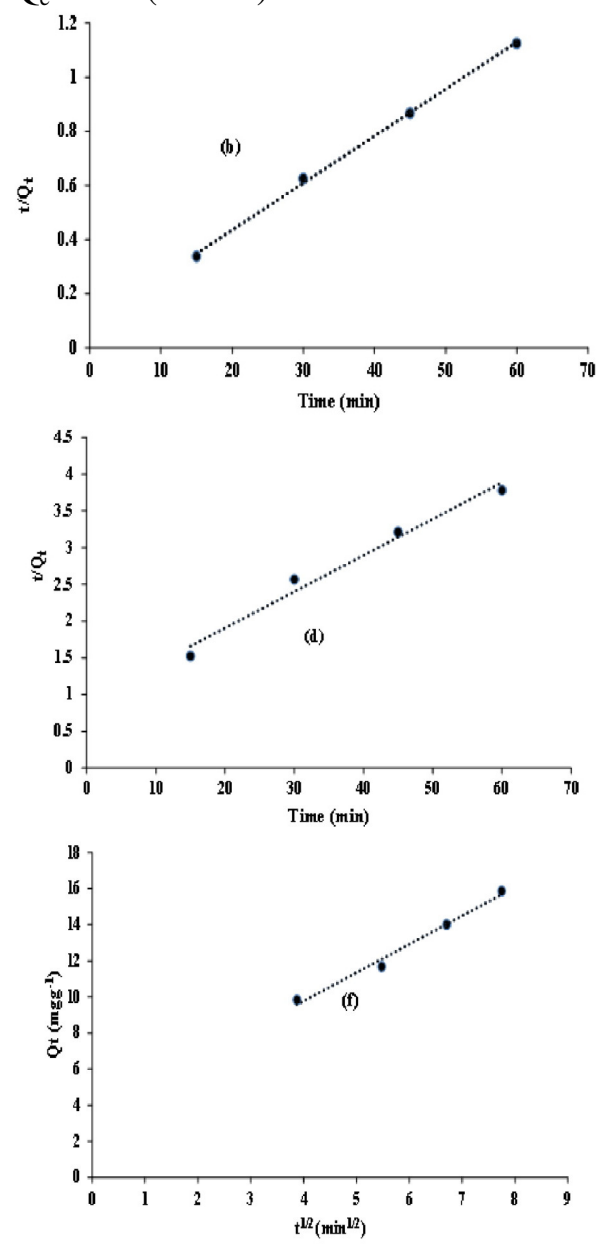
Table 3

Kinetic parameters for adsorption of $\mathrm{MG}$ and $\mathrm{CR}$ onto stinging nettle

\begin{tabular}{lccc}
\hline Models & Parameter & $\mathrm{MG}$ & $\mathrm{CR}$ \\
\hline \multirow{3}{*}{ Pseudo-first-order kinetic model } & $\mathrm{k}_{1}\left(\mathrm{~min}^{-1}\right)$ & 0.0141 & 0.0067 \\
& $\mathrm{Q}_{\mathrm{e}}\left(\mathrm{mgg}^{-1}\right)$ & 19.976 & 15.791 \\
& $\mathrm{R}^{2}$ & 0.9875 & 0.9894 \\
\hline \multirow{2}{*}{ Pseudo-second-order kinetic } & $\mathrm{k}_{2}\left(\mathrm{mgg}^{-1} \min ^{-1}\right)$ & 0.0034 & 0.0026 \\
model & $\mathrm{Q}_{\mathrm{e}}\left(\mathrm{mgg}^{-1}\right)$ & 57.471 & 20.243 \\
& $\mathrm{R}^{2}$ & 0.9988 & 0.9780 \\
\hline \multirow{2}{*}{ Intraparticle diffusion } & $\mathrm{K}_{\mathrm{i}}$ & 2.4058 & 1.5737 \\
& $\left.\mathrm{c}^{-1} \mathrm{mgg}^{-1}\right)$ & 35.037 & 3.4796 \\
& $\mathrm{R}^{2}$ & 0.9852 & 0.9865 \\
\hline
\end{tabular}

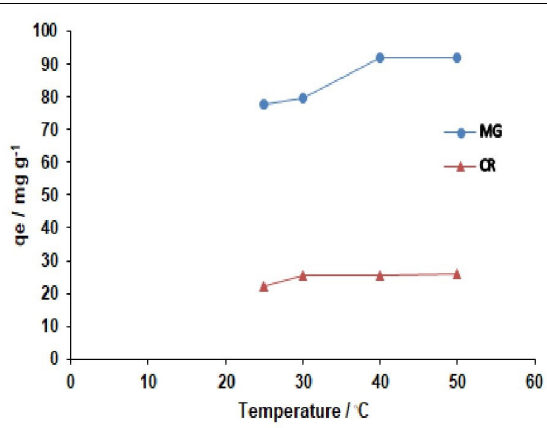

Figure 6: Effect of temperature on adsorption of MG and CR onto stinging nettle

The intraparticle diffusion model was also used to identify the adsorption mechanism and kinetics. If the plot of $\mathrm{Q}_{t}$ versus $\mathrm{t}^{1 / 2}$ is linear and passes through the origin, it means the intraparticle diffusion is the sole rate-limiting step. In Figure 5 (e) and (f), the plots of $\mathrm{Q}_{\mathrm{t}}$ versus $\mathrm{t}^{1 / 2}$ are linear, but do not pass through the origin, indicating that surface adsorption and intraparticle diffusion were both efficient during the interactions between the dye molecules and the adsorbent. In addition, the high $\mathrm{R}^{2}$ values indicated that the intraparticle model played a significant role in the adsorption mechanism. ${ }^{74}$

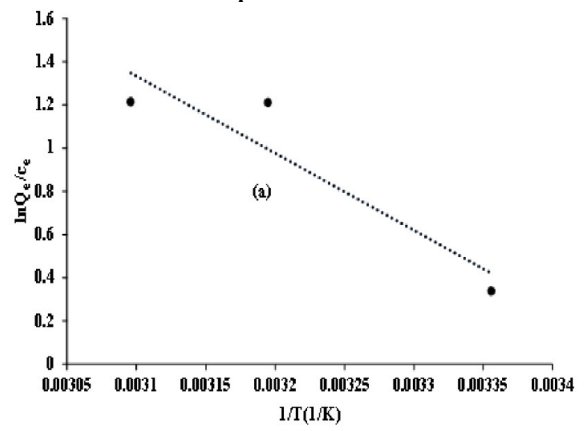

Figure 7: Van't Hoff plot for adsorption of MG (a) and CR (b) onto stinging nettle

\section{Effect of temperature and thermodynamic analysis}

Temperature is one of the most important parameters in the adsorption process. The effect of temperature varying between $25^{\circ} \mathrm{C}$ and $50{ }^{\circ} \mathrm{C}$ on adsorption was investigated and it was determined that as the temperature rose, the adsorption increased, but this increase was not noticeable for the adsorption of $\mathrm{CR}$ onto the stinging nettle (Fig. 6).

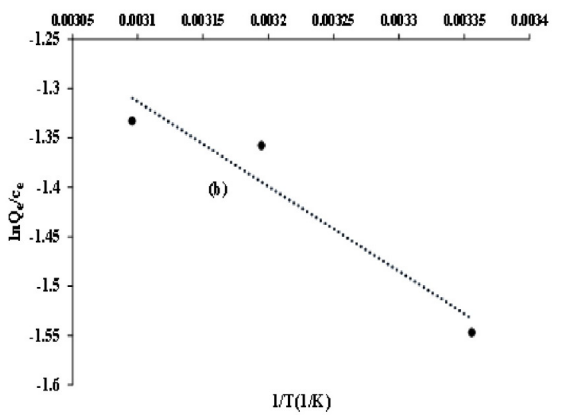

When the temperature rises, the solubility, kinetic energy, and mobility of the dye molecules increase, while their viscosity decreased. As a result, the diffusion rate of the dye molecules from the outer boundary layer into the pores on the stinging nettle surface was increased and adsorption intensified. Thermodynamic parameters, i.e. Gibbs' free energy $\left(\Delta \mathrm{G}^{\circ}\right)$, 
enthalpy change $\left(\Delta \mathrm{H}^{\circ}\right)$ and entropy change $\left(\Delta \mathrm{S}^{\circ}\right)$, were calculated from the Van't Hoff plots (in Fig. 7) and presented in Table 4. Negative values of Gibbs' free energy change for all experiments imply that the dye adsorption process was spontaneous and positive values of enthalpy change indicated that the dye adsorption process is endothermic in nature. The positive values of $\Delta \mathrm{S}^{\circ}$ mean increasing randomness at the solidliquid interface of the dye molecules on the active sites of the adsorbent during the adsorption process. Similar results have been obtained by other researchers. $^{72,73,75}$

Table 4

Thermodynamic parameters for adsorption of $\mathrm{MG}$ and $\mathrm{CR}$ onto stinging nettle

\begin{tabular}{ccccccc}
\hline \multirow{2}{*}{$\begin{array}{c}\text { Temperature } \\
{ }^{\circ} \mathrm{C}\end{array}$} & \multicolumn{3}{c}{$\mathrm{MG}$} & \multicolumn{3}{c}{$\mathrm{CR}$} \\
\cline { 2 - 6 } & $\begin{array}{c}\Delta \mathrm{G}^{0} \\
\left(\mathrm{kJmol}^{-1}\right)\end{array}$ & $\begin{array}{c}\Delta \mathrm{H}^{0} \\
\left(\mathrm{kJmol}^{-1}\right)\end{array}$ & $\begin{array}{c}\Delta \mathrm{S}^{0} \\
\left(\mathrm{kJmol}^{-1} \mathrm{~K}^{-1}\right)\end{array}$ & $\begin{array}{c}\Delta \mathrm{G}^{0} \\
\left(\mathrm{kJmol}^{-1}\right)\end{array}$ & $\begin{array}{c}\Delta \mathrm{H}^{0} \\
\left(\mathrm{kJmol}^{-1}\right)\end{array}$ & $\begin{array}{c}\Delta \mathrm{S}^{0} \\
\left(\mathrm{kJmol}^{-1} \mathrm{~K}^{-1}\right)\end{array}$ \\
\hline 25 & -1.047 & 29.647 & 0.103 & -3.856 & 7.134 & 0.011 \\
40 & -2.592 & & & -3.691 & & \\
50 & -3.622 & & & -3.581 & & \\
\hline
\end{tabular}

\section{CONCLUSION}

Recently, studies have been carried out on the use of agricultural wastes as adsorbents for the removal of dyes, heavy metals, organic and nutrient pollutants. In this study, the adsorption performance of stinging nettle towards anionic dye $\mathrm{CR}$ and cationic dye MG were compared and the adsorption mechanism of the two types of dyes was attempted to be explained with isotherm, kinetic and thermodynamic data. The stinging needle was characterized by FTIR before and after adsorption; it was determined that it predominantly contains polyhydroxy groups that bind dye molecules, and the changes in the spectra after adsorption confirmed this interaction. The adsorption process has been found to be well described by the Langmuir isotherm model, with a maximum adsorption capacity of $270.27 \mathrm{mgg}^{-1}$ at $\mathrm{pH} 6,172.14 \mathrm{mgg}^{-1}$ at $\mathrm{pH} 7$ for MG and CR, respectively, and these values are quite high when compared to other adsorbents. The $\mathrm{pH}$ range for the maximal values of adsorption capacity corresponds to that of natural water sources - this offers the advantage of using the adsorbent without any $\mathrm{pH}$ adjustment. The kinetic data fitted well with the pseudo-second-order model for $\mathrm{MG}$ and the pseudo-first-order model for CR adsorption. Intraparticle diffusion is also involved in the adsorption process. The fact that the pseudosecond-order model gives better results in $\mathrm{MG}$ adsorption and the $\Delta \mathrm{H}^{\circ}$ value is greater than $10 \mathrm{~kJ}$ supports the chemical adsorption of MG.

It has been revealed that stinging nettle, which is a commonly found plant in nature and does not require special conditions for growth, can be used as an effective adsorbent for anionic and cationic dyes. In addition to its lignocellulosic structure, its good chemical stability and suitable mechanical properties in both acidic and basic media, are factors that recommend the use of stinging nettle as an adsorbent for bioremediation.

ACKNOWLEDGEMENTS: The author would like to thank Giresun University for allowing to use the research equipment at Espiye Vocational School and Central Research Laboratory.

\section{REFERENCES}

1 Ö. E. İşmal, Yedi: Sanat, Tasarım ve Bilim Dergisi, 22, 41 (2019), https://doi.org/10.17484/yedi.547726

2 D. Pokhrel and T. Viraraghavan, Sci. Total Environ., $\quad 333, \quad 37 \quad$ (2004), https://doi.org/10.1016/j.scitotenv.2004.05.017

3 F. P. Van Der Zee, Doctoral Thesis, Wageningen University, Wageningen, The Netherlands, 2002, 142 pages

4 M. Işık and D. T. Sponza, Ekol.: Cevre Derg., 14, 1 (2004)

5 V. M. Chung and S. E. Stevens, Environ. Toxicol. Chem., $\quad 12, \quad 2121 \quad$ (1993), https://doi.org/10.1002/etc.5620121120

${ }^{6}$ G. Kalemtaş, Master Thesis, Eskişehir Osmangazi Üniversitesi, 2012

7 B. Donlon, E. Razo-Flores, M. Luijten, H. Swarts, G. Lettinga et al., Appl. Microbiol. Biotechnol., 47, 83 (1997), https://doi.org/10.1007/s002530050893

8 P. Rajaguru, K. Kalaiselvi, M. Palanivel and V. Subburam, Appl. Microbiol. Biotechnol., 54, 268 (2000), https://doi.org/10.1007/s002530000322

9 A. Erkuş, E. Oygun, M. Türkmenoğlu and A. Aldemir, Yuzuncu Yil Univ. J. Inst. Nat. Appl. Sci, 23, 308 (2018) 
10 T. Robinson, G. McMullan, R. Marchant and P. Nigam, J. Biores. Technol., 77, 247 (2001), https://doi.org/10.1016/s0960-8524(00)00080-8

11 R. Qadeer, Colloids Surf. A: Physicochem. Eng. Aspects, 293, $217 \quad$ (2007), https://doi.org/10.1016/j.colsurfa.2006.07.035

12 V. C. Srivastava, I. D. Mall and I. M. Mishra, Chem. Eng. J., 132, 267 (2007), http://dx.doi.org/10.1016/j.cej.2007.01.007

13 M. E. Argun, S. Dursun, C. Ozdemir and M. Karatas, J. Hazard. Mater., 141, 77 (2007), https://doi.org/10.1016/j.jhazmat.2006.06.095

14 A. Ahmad and B. Hameed, J. Hazard. Mater., 172, 1538

(2009),

https://doi.org/10.1016/j.jhazmat.2008.08.084

15 N. El Hannafi, M. A. Boumakhla, T. Berrama and Z. Bendjama, Desalination, 223, 264 (2008), https://doi.org/10.1016/j.desal.2007.01.229

16 M. A. Ahmad, W. M. A. Wan Daud and M. K. Aroua, Colloids Surf. A: Physicochem. Eng. Aspects, 312, 131

(2008),

https://doi.org/10.1016/j.colsurfa.2007.06.040

17 M. Arulkumar, P. Sathishkumar and T. Palvannan, J. Hazard. Mater., 186, 827 (2011), https://doi.org/10.1016/j.jhazmat.2010.11.067

18 P. Leechart, W. Nakbanpote and P. Thiravetyan, J. Environ. Manag., 90, $912 \quad$ (2009), https://doi.org/10.1016/j.jenvman.2008.02.005

19 H. Sayğılı and F. Güzel, Chem. Eng. Res. Des., 100, 27

(2015),

https://doi.org/10.1016/j.cherd.2015.05.014

20 B. Hameed and M. El-Khaiary, J. Hazard. Mater., 157, 344

(2008),

https://doi.org/10.1016/j.jhazmat.2007.12.105

21 I. D. Mall, V. C. Srivastava, N. K. Agarwal and I. M. Mishra, Chemosphere, 6, 492 (2005), https://doi.org/10.1016/j.chemosphere.2005.03.065

22 I. D. Mall, V. C. Srivastava, N. K. Agarwal and I. M. Mishra, Colloids Surf. A: Physicochem. Eng. Aspects, $\quad \mathbf{2 6 4}, \quad 17 \quad$ (2005), https://doi.org/10.1016/j.colsurfa.2005.03.027

23 O. S. Bello and M. A. Ahmad, Sep. Sci. Technol., 47, 6

(2012),

https://doi.org/10.1080/01496395.2011.630335

24 M. Sriuttha, K. Wittayanarakul, B. Hemung and W. Tongpoothorn, Asian J. Chem., 26, 110 (2014), https://doi.org/10.14233/ajchem.2014.19043

${ }_{25}$ G. Sun and X. Xu, Ind. Eng. Chem. Res., 36, 808 (1997), https://doi.org/10.1021/IE9603833

26 C. Namasivayam and D. Kavitha, Dyes Pigm., 54, 47 (2002), http://dx.doi.org/10.1016/S01437208(02)00025-6

27 K. G. Bhattacharyya and A. Sharma, J. Environ. Manag., $\quad \mathbf{7 1}, \quad 217 \quad$ (2004), https://doi.org/10.1016/j.jenvman.2004.03.002

28 M. C. Somasekhara and M. Reddy, J. Sci. Ind. Res., 65, $443 \quad$ (2006),

https://doi.org/10.1016/j.dyepig.2006.06.009
29 N. A. Oladoja and A. K. Akinlabi, Ind. Eng. Chem. Res., $\quad 48, \quad 6188 \quad$ (2009), https://doi.org/10.1021/ie801003v

30 P. S. Kumar, S. Ramalingam, C. Senthamarai, M. Niranjanaa, P. Vijayalakshmi et al., Desalination, 261, 52

(2010),

http://dx.doi.org/10.1016/j.desal.2010.05.032

31 S. Dawood and T. K. Sen, Water Res., 46, 1933 (2012), http://dx.doi.org/10.1016/j.watres.2012.01.009

32 A. Roy, S. Chakraborty, S. P. Kundu, B. Adhikari and S. B. Majumder. J. Appl. Polym. Sci., 129, 15 (2013), https://doi.org/10.1002/app.38222

33 A. S. Franca, L. S. Oliveira and M. E. Ferreira, Desalination, 249, $267 \quad$ (2009), https://doi.org/10.1016/j.desal.2008.11.017

34 S. Chowdhury, R. Misra, P. Kushwaha and P. Das, Biorem. J., $\quad \mathbf{1 5}, \quad 77 \quad$ (2011), https://doi.org/10.1080/10889868.2011.570282

35 A. Demirbas, J. Hazard. Mater., 167, 1 (2009), https://doi.org/10.1016/j.jhazmat.2008.12.114

36 H. Hirofimi, I. Takonori and K. Ryuichiro, Enzyme Microb. Tech., 30, 467 (1999), https://doi.org/10.1016/S0141-0229(02)00009-1

37 A. K. Adesina and B. Olugbenga, Water Resour. Ind., $\quad \mathbf{1 2}, \quad 8 \quad$ (2015), https://doi.org/10.1016/j.wri.2015.09.002

38 L. Bacci, S. Di Lonardo, L. Albanese, G. Mastromei and B. Perito, Text. Res. J., 81, 827 (2011), https://doi.org/10.1177/0040517510391698

39 L. Grauso, B. de Falco, V. Lanzotti and R. Motti, Phytochem. Rev., 19, $1341 \quad$ (2020), https://doi.org/10.1007/s11101-019-09607$1(0123456789$

40 M. A. G. Maobe and R. M. Nyarango, World Sci. J., 21, $1128 \quad$ (2013), http://citeseerx.ist.psu.edu/viewdoc/download

41 N. Di Virgilio, E. G. Papazoglou, Z. Jankauskiene, S. Di Lonardo, M. Praczyke et al., Ind. Crop. Prod., 68, $42 \quad$ (2015), https://doi.org/10.1016/j.indcrop.2014.08.012

42 V. D. Dimitrijević, M. N. Stanković, D. M. Đorđević, I. M. Krstıć, M. G. Nikolıć et al., Studia

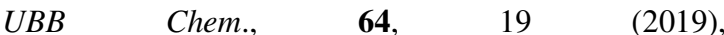
https://doi.org/10.24193/subbchem.2019.1.02

43 B. Ertan, S. Gurkok and D. Efe, Studia UBB Chem., $\quad 64, \quad 109 \quad$ (2020), https://doi.org/10.24193/subbchem.2020.4.09

44 G. Derafa and H. Zaghouane-Boudiaf, Int. J. Biol. Macromol., $\quad$ 124, $915 \quad$ (2019), https://doi.org/10.1016/j.ijbiomac.2018.11.253

${ }^{45}$ L. J. Han, B. T. Su, G. Liu, Z. Ma and X. C. An, Mol. Catal., 456, $96 \quad$ (2018), https://10.1016/j.mcat.2018.07.006

${ }^{46}$ H. M. F. Freundlich, Z. Phys. Chem., 57, 385 (1906), https://doi.org/10.1515/zpch-1907-5723

47 I. Langmuir, J. Am. Chem. Soc., 40, 1361 (1918), https://doi.org/10.1021/ja02242a004

${ }^{48}$ Y. Tian, C. Ji and M. Zhao, Chem. Eng. J., 165, 474 (2010), https://doi.org/10.1016/j.cej.2010.09.037 


\section{BENGÜ ERTAN}

49 S. Lagergren, "Zurtheorie der sogenannten adsorption gelosterstoffe", Kungliga Svenska Vetenskaps akademiens, Handlingar, 1898, pp. 1-39

50 D. O. Hayward, B. M. W Trapnell and W. Garden, "Butterworths", London, 1964, pp. 67-159, https://doi.org/10.1016/0021-9517(65)90096-5

51 W. J. Weber and J. C. Morris, J. Sanit. Eng. Div., 89, 31 (1963)

52 P. Atkins and J. de Paula, "Physical Chemistry", $9^{\text {th }}$ ed., W. H. Freeman and Company, New York, 2010

53 R. Chang and J. W. Thoman Jr., "Physical Chemistry for the Chemical Sciences", University Science Books, Canada, 2014

54 J. G. Buta, F. Zadrazil and G. C. Galletti, J. Agric. Food Chem., 37, $1382 \quad$ (1989), https://doi.org/10.1021/JF00089A038

55 R. C. Sun and J. Tomkinson, Ultrason. Sonochem., 9, 85 (2002), https://doi.org/10.1016/S13504177(01)00106-7

56 C. P. Sekhar, S. Kalidhasan, V. Rajesh and N. Rajesh, Chemosphere, 77, $842 \quad$ (2009), https://doi.org/10.1016/j.chemosphere.2009.07.068

57 D. Yuang, D. Fu and C. Wang, Sep. Sci. Technol., 56, 233 https://doi.org/10.1080/01496395.2020.1715435

58 A. F. Hassan, A. M. Abdel-Mohsen and M. M. G. Fouda, Carbohyd. Polym., 102, 192 (2014), https://doi.org/10.1016/j.carbpol.2013.10.104

59 K. Pandi and N. Viswanathan, Carbohyd. Polym., 112 662 (2014) https://doi.org/10.1016/j.carbpol.2014.06.029 60 T. A. Khan, S. Dahiya and I. Ali, Appl. Clay Sci., 69, 58

(2012),

https://doi.org/10.1016/j.clay.2012.09.001

61 N. Atar, A. Olgun, S. Wang and S. Liu, J. Chem. Eng. Data, 56, 508 (2011), https://doi.org/10.1021/je100993m
62 F. A. Pavan, E. C. Lima, S. L. Dias and A. C. Mazzocato, J. Hazard. Mater., 150, 703 (2008), https://doi.org/10.1016/j.jhazmat.2007.05.023

63 J. Fu, Z. Chen, M. Wang, S. Liu, J. Zhang et al., Chem. Eng. J., 259, $53 \quad$ (2015), https://doi.org/10.1016/j.cej.2014.07.101

64 B. Chen, Y. R. Cao, H. N. Zhao, F. X. Long, X. Feng et al., J. Hazard. Mater., 392, 15 (2020), https://doi.org/10.1016/j.jhazmat.2020.122263

65 F. Çolak, N. Atar and A. Olgun, Chem. Eng. J., 150 122

(2009),

https://doi.org/10.1016/j.cej.2008.12.010

${ }^{66}$ K. R. Hall, L. C. Eagleton, A. Acrivos and T. Vermeulen, Ind. Eng. Chem. Fundam., 5, 212 (1966), https://doi.org/10.1021/i160018a011

67 X. Guo and J. Wang, Environ. Pollut., 250, 737 (2019), https://doi.org/10.1016/j.envpol.2019.04.091

68 S. Mondal and S. K. Majumder, J. Environ. Chem. Eng., 7, $103236 \quad$ (2019), https://doi.org/10.1016/j.jece.2019.103236

${ }_{69}$ Y. Liu, H. A. Li, Y. Tian, Z. Jin and H. Deng, Fuel, 218, 67

(2018),

https://doi.org/10.1016/j.fuel.2018.01.012

70 M. Berrios, M. A. Martınan and A. Martin, J. Ind. Eng. Chem., 18, $780 \quad$ (2012), https://doi.org/10.1016/j.jiec.2011.11.125

71 W. Ma, X. Song, Y. Pan, Z. Cheng, X. Gang et al., Chem. Eng. J., 193-194, $381 \quad$ (2012), https://doi.org/10.1016/j.cej.2012.04.049

72 Y. Safa and H. N. Bhatti, Desalination, 272, 313 (2011), http://dx.doi.org/10.1016/j.desal.2011.01.040

73 W. C. Qian, X. P. Luo, X. Wang, M. Guo and B. Li, Ecotoxicol. Environ. Saf., 157, 300 (2018), https://doi.org/10.1016/j.ecoenv.2018.03.088

74 Y. S. Ho, Water Res., 37, 2323 (2003), https://doi.org/10.1016/S0043-1354(03) 00002-2

75 N. Nasuha and B. H. Hameed, Chem. Eng. J., 166, 783 (2011), https://doi.org/10.1016/j.cej.2010.11.012 